Prace Historyczno-Archiwalne t. XXXII

ISSN: 1231-3335

\author{
Krzysztof Śmiechowski \\ ORCID 0000-0002-1487-7650 \\ DOI: $10.30657 /$ pha.32.2020.04 \\ (historyk, Rzeszów) \\ e-mail: ksm66 ksm66@o2.pl
}

\title{
Z „Sokiłem” w tle. Powstanie i rozwój ukraińskich organizacji gimnastyczno-pożarniczych „Sicz” (1900-1914)
}

\section{Streszczenie}

Z końcem lat siedemdziesiątych XIX w., wraz z autonomią Galicji i uzyskaniem przez mniejszości narodowe szeregu ustępstw ze strony monarchii austriackiej, nastąpił wyraźny wzrost ich narodowej świadomości. Możliwym wówczas stało się zakładanie organizacji i towarzystw. Skorzystali z tego także i galicyjscy Ukraińcy, którzy zaczęli - głównie z inicjatywy „Proswity” - zakładać własne oświatowe, kulturalne i gospodarcze instytucje, a także towarzystwa sportowe, czego doskonałym przykładem był „Sokił”.

Jednakże trzy lata od jego powstania tarcia wewnętrzne w tym towarzystwie spowodowały zastój jego działalności i groźbę rozwiązania. Ten chwilowy paraliż i powstałą w tym obszarze lukę sprawnie wypełniła organizacja założona przez radykała Kyryła Trylowśkiego. Było nią Towarzystwo Gimnastyczno-Pożarnicze „Sicz”, które w stosunkowo krótkim czasie, z pojedynczej komórki, rozwinęło się w sprawnie działający związek, zrzeszający do wybuchu wojny, na terenie Galicji, ponad 800 filii.

„Sicz” zaczęła opanowywać przestrzeń powstałą po niepewnym i niestabilnym w tamtym czasie „Sokile”, stając się tym samym alternatywą dla tych, którzy w rozwój „Sokiła” zdążyli już zwątpić. Tym, co miało przyciągać w szeregi młodej organizacji zwolenników i odróżniać nowo powstałą inicjatywę od opartego na specyfice słowiańskiej „Sokiła”, był stricte narodowy fundament „Siczy” i jej ukierunkowanie na wiejskie masy z zamiarem ich połączenia pod szyldem jednej, wielkiej, gimnastyczno-przeciwpożarowej organizacji. Jak czas pokazał, popularność „Siczy” wynika nie z tego, że była ona zrzeszeniem pożarniczo-gimnastycznym, lecz przede wszystkim - prężną instytucją krzewiącą historię, kulturę i tradycje narodowe.

Zarówno ruch sokilski, jak i siczowy, działając obok siebie przez kilkanaście lat, z niewielkich, pojedynczych towarzystw rozrosły się w sprawne i szeroko rozgałęzione organizacje, stanowiąc na początku XX w. dwa najpotężniejsze ogniska ukraińskiego ruchu gimnastycznego i przeciwpożarowego. Obie centrale, choć niechętne 
wzajemnie, przez całe lata przenikały się dość wyraźnie, popularyzując sprawę tożsamości i odrodzenia narodowego i kształtując we właściwy sobie sposób ukraińskie społeczeństwo. Rywalizując, każda z nich aspirowała do tego, by na gruncie fizycznego odrodzenia zostać przewodnią siłą narodu.

Kiedy obie organizacje stanowiły już liczącą się siłę, a ich idea została dostatecznie wypromowana, „sokilsko-siczowemu dziełu” brakowało jedynie konsolidacji, gdyż obu centralom wróżono świetlaną przyszłość, ale pod jednym sztandarem. Jednakże z powodu zbyt dużych różnic: politycznych, kulturowo-historycznych, metodycznych, religijnych czy nawet kwestii ambicjonalnych dzielących oba stowarzyszenia - do takowej konsolidacji nigdy nie doszło.

\section{Słowa kluczowe:}

Ukraińskie towarzystwo gimnastyczno-pożarnicze „Sicz”, Sicz, Sokił, ukraińskie towarzystwo sportowe, Trylowski, Główny Komitet Siczowy, Ukraiński Związek Siczowy

W połowie lat siedemdziesiątych XIX w., na terenie Galicji, pojawiła się grupa młodej ukraińskiej inteligencji, która dość krytycznie zaczęła się odnosić do istniejących wówczas dwóch nurtów: moskalofilskiego i stojącego doń w opozycji ruchu narodowego. Zwłaszcza ruchowi narodowemu grupa ta chciała nadać bardziej europejski charakter, a deklarowana europejskość miała polegać na orientacji w kierunku socjalizmu. Z braku dostatecznego zrozumienia, jej odłam reprezentowany m.in. przez działaczy politycznych: Iwana Frankę, Mychajło Pawłyka i Ostapa Terłećkiego, zainicjował powstanie trzeciego w ukraińskim obozie, ruchu - radykalnego ${ }^{1}$. Chociaż zwolenników nowego kierunku nie było wielu, z czasem potrafili oni odegrać istotną rolę w zmianie postaw ideologicznych Ukraińców. Prowadząc intensywną propagandę polityczną wśród ukraińskiego chłopstwa i warstw robotniczych, krytykując przy tym duchowieństwo, nierzadko postrzegani byli jako mąciciele spokoju wśród mieszkańców Galicji ${ }^{2}$. W 1890 r. ich staraniem powstała pierwsza ukraińska partia polityczna pod nazwą: Rusko-Ukrajinśka Partia Radykalna (RURP) ${ }^{3}$.

Jednym ze współzałożycieli RUPR, gorącym, wręcz fanatycznym jej zwolennikiem i działaczem był adwokat, poseł do parlamentu wiedeńskiego, „kozakofil” i pasjonat dawnej „Siczy Zaporoskiej” - Kyrył (Cyryl) Trylowśkyj ${ }^{4}$. Na IX zjeździe

1 Narodziny ruchu w latach 1877-1878 poprzedził wytoczony we Lwowie proces sądowy przeciwko socjaliście Iwanowi Franko i jego towarzyszom. J. Hrycak, Historia Ukrainy 1772-1999. Narodziny nowoczesnego narodu, Lublin 2000, s. 94.

2 Ibidem, s. 95.

3 Wewnątrzpartyjne dyskusje wykrystalizowały ideę politycznej niepodległości Ukrainy, która została opisana w roku 1895 w książce Ukrajina irredenta młodego marksisty radykała Juliana Baczynśkiego. Z końcem lat dziewięćdziesiątych XIX w. z Radykalnej Partii oddzieliło się skrzydło marksistowskie, które w roku 1899 utworzyło Ukrajinśką Partię Socjaldemokratyczną z Mykołą Hankewyczem, Julianem Baczynśkim i Semenem Witykiem jako liderami. Zob.: J. Hrycak, Historia Ukrainy..., s. 95.

4 Kyrył (Cyryl) Trylowśkyj urodził się 6 maja 1864 r. w rodzinie greckokatolickiego duchownego w miejscowości Bohutyn. Uczęszczał do szkoły w Złoczowie i Brodach. Naukę konty- 
partii (17-18 grudnia 1899), przy udziale 54 delegatów reprezentujących 16 powiatów i w obecności 107 zaproszonych galicyjskich chłopów, Trylowśkyj wygłosił mowę, w której przestrzegał zebranych przed największymi zagrożeniami stojącymi na przeszkodzie rozwojowi młodej partii, a jako głównego wroga wskazywał obcy Ukraińcom rząd i „panów”. Kolejnego, wewnętrznego wroga, upatrywał w klerze i moskalofilach ${ }^{5}$. Było to wydarzenie o tyle istotne, że niedługo mówca miał przekuć swoje obawy i pragnienia w czyn.

Trylowśkyj w najniższych warstwach społeczeństwa miał wielu zwolenników. Jego popularność szczególnie wzrosła po roku 1902, kiedy aktywnie wspierał chłopów w ich protestach przeciwko „polskim dziedzicom”. Wykorzystując swój autorytet, postanowił własne poglądy, przekonania i pasje przenieść na szerokie ukraińskie masy, a do tego potrzeba było czegoś więcej aniżeli partii politycznej. Potrzeba było powszechnego ruchu, organizacji zdolnej zrzeszyć pod wspólnym szyldem szerokie masy chłopstwa, a te w strukturze ludnościowej Ukraińców stanowiły warstwę dominującą. Kłopot polegał na tym, że większość z nich, blisko 80\%, stanowili analfabeci ${ }^{7}$. Dlatego zaszczepienie jakiejkolwiek idei wśród nieuświadomionych warstw chłopstwa musiałoby spotkać się z niezrozumieniem, okazać się czymś mało realnym, a tym samym, z góry skazanym na niepowodzenie. W realizacji celu, sprzymierzeńcem okazała się powszechna bojaźń przed jedną z ówczesnych plag galicyjskich wsi - pożarami. Nic tak bowiem nie działało na wyobraźnię i nie pobudzało do aktywności jak perspektywa utraty własnego mienia. Groźba pożaru okazała się dostateczną motywacją do utworzenia towarzystw, zdolnych zorganizować chłopów w sprawne, zdyscyplinowane oddziały, dające im przy okazji konkretne i realne korzyści. Wprawdzie tworzone oddziały należało jeszcze odpowiednio wyposażyć, otoczyć opieką szkoleniową i prawną, ale przy okazji odpowiednio ukierunkowując ideologicznie, pobudzając narodowo, można

nuował w gimnazjum w Brodach i Kołomyi. Następnie studiował prawo na uniwersytetach we Lwowie i Wiedniu. Po studiach otworzył kancelarię adwokacką w Kołomyi. Działalność polityczną rozpoczął jeszcze w gimnazjum w Złoczowie, gdzie w czerwcu $1878 \mathrm{r}$. w wieku dwunastu lat założył pierwsze „Tajne koło” zajmujące się szerzeniem ruskiego ducha wśród gimnazjalistów. Studiując we Lwowie, został liderem towarzystwa „Akademyczne Bratstwo” i współzałożycielem towarzystw: „Narodna Spiłka” i „Narodna Wola”. Dużo publikował. W latach 1896-1897 w Kołomyi wydawał gazetę „Hromada”. W 1893 r. w Śniatyniu założył towarzystwo biblioteczne „Nauka”. Współzałożyciel Radykalnej Partii. W 1907 r. został wybrany do wiedeńskiego parlamentu. Od 1913 r. poseł do Sejmu Galicyjskiego we Lwowie. Największą jego pasją była praca na rzecz założenia i rozbudowy ruchu siczowego. Autor, redaktor, wydawca czasopism, śpiewników, kalendarzy, broszur. Po I wojnie światowej przebywał na emigracji w Wiedniu. Pracował tam jako członek komisji kodyfikacyjnej powołanej przy rządzie ZUNR dra J. Petruszewycza. W tym czasie pisał także do ukraińskich gazet wychodzących w Stanach Zjednoczonych i w Kanadzie. Z emigracji powrócił w 1928 r. Niedaleko Kołomyi, w miasteczku Gwoździec, ponownie otworzył kancelarię adwokacką. Brał czynny udział w życiu społecznym. Zmarł w październiku 1941 r. w Kołomyi, gdzie został pochowany.

5 B. Trofymiak, Himnastyczno-sportywni orhanizaciji $w$ nacionalno-wyzwolnomu rusi Hałyczyny, druha poł. XIX st. - persza poł. XX st., Ternopil 2001, s. 213.

6 S. Zaborniak, Kultura fizyczna ludności ukraińskiej na ziemiach polskich (1868-1939), Rzeszów 2007, s. 221.

7 T. Dąbkowski, Ukraiński ruch narodowy w Galicji Wschodniej 1912-1923, Warszawa 1985, s. 40. 
było wychować całkiem spore zaplecze polityczne. Wzorce pod taką organizację były gotowe, gdyż już od kilku lat podobną działalność w kręgach ukraińskiego społeczeństwa prowadziło towarzystwo „Sokił” („Sokół”) ${ }^{8}$. Rzecz w tym, że od roku 1897 organizacja ta coraz bardziej popadała w głęboki kryzys wewnętrzny, wszelka jej działalność ustawała, a nad samym „Sokiłem” zawisła groźba rozwiązania. Tę próżnię postanowił wykorzystać Trylowśkyj tworząc podwaliny własnego ruchu siczowego.

Zamiast poszukiwać nowych form ruchu i korzystać z zapożyczeń najpopularniejszych europejskich systemów, Trylowśkyj postanowił utworzyć odmienny, rodzimy ruch, nawiązując przy tym do tradycji kozackich i Siczy Zaporoskiej. Pierwsze kroki pod nową inicjatywę zostały poczynione przez Trylowśkiego we wsi Uście nad Prutem w roku $1899^{9}$. Wniesienie do rejestracji pierwszego statutu „Siczy” zbiegło się dokładnie ze wspomnianym wyżej okresem zastoju w działalności ukraińskiego „Sokiła”, spowodowanym przez ostre tarcia polityczne wśród członków jego zarządu. Pierwszy statut nowego towarzystwa złożony przez radykała w namiestnictwie lwowskim, nie został przyjęty ze względu na zamieszczone w jednym z paragrafów prawo do noszenia odznak i szarf, co nie spodobało się władzom. Kolejny statut, poprawiony, wniesiony przez grupę inicjatywną ze wsi o nazwie Zawale w powiecie śniatyńskim, został przyjęty przez namiestnictwo 8 marca $1900 \mathrm{r}^{10}{ }^{10}$, zaś 5 maja 1900 r., zebranie założycielskie, w którym brało udział dwieście osób, powołało do życia pierwsze Gimnastyczno-Przeciwpożarowe Towarzystwo „Sicz”11. Koszowym (naczelnikiem) pierwszej „Siczy” został Mykoła Nediłka, a esaułem Mychajło Odynśki. „Sicz” wypełniła lukę powstałą po niepewnym i niestabilnym w tamtym czasie „Sokile”, stając się tym samym alternatywą dla tych, co w rozwój „Sokiła”zdążyli już zwątpić. Jak głosił sam pomysłodawca „Siczy”, tym, co w pierwszej kolejności miało odróżniać przyszłe towarzystwa „siczowe” od istniejących „sokilskich”, było skierowanie działalności towarzystwa na wiejskie masy i zjednoczenie ich w jednej, wielkiej gimnastyczno-przeciwpożarowej organizacji. Kolejną intencją twórcy było wdrożenie chłopów do, choćby najlżejszych, ale co ważne, masowo i wspólnie wykonywanych ćwiczeń, a także wpojenie im poczucia wolności, równości i braterstwa ${ }^{12}$. Gimnastyka „siczowa”, w odróżnieniu od „sokilskiej”, nie miała na celu fizycznego odrodzenia narodu, choćby z braku odpowiednich kadr instruktorskich i zaplecza sportowego, ale miała stanowić istotny środek wychowawczy, dyscyplinujący i przygotowujący do pracy zespołowej, a także przeciwwagę dla panujących wśród chłopskich mas nałogów.

„Sicze” przynosiły swoim członkom zarówno korzyść fizyczną, jak i duchową. Poprzez zaprawę rozwijały cieleśnie. Chociaż nie były organizacjami czysto gimnastycznymi, to ich zasługa w rozpropagowaniu ćwiczeń gimnastycznych na

8 Ukraińskie Towarzystwo Gimnastyczne „Sokił” powstało 11 lutego 1894 r. CDIAUL, F. 312, op. I, spr. 37, s. 1-2 (Księga protokołów 1894-1902).

9 B. Trofymiak, Himnastyczno-sportywni orhanizaciji..., s. 222.

10 CDIAUL, F. 312, op. I, spr. 7. Statut przyjęty reskryptem (nr 16995) c.k. Namiestnictwa w dniu 8 marca 1900 r. Z okazji powstania pierwszej „Siczy” Trylowśkyj ułożył pieśń: Pro Sicz sławnu - Zaporoże.

11 B.I. Kowerko, Sokilśkyj i siczowyj himnastycznyj ruch u Hałyczyni na poczatku XX stolittia [w:] Tradycji fizycznoji kultury w Ukrajini. Zbirnyk naukowych stattej, Kyjiw 1997, s. 70.

12 CDIAUL, F. 312, op. I, spr. 169, ark. 4. 
terenach wiejskich stała się bezsprzeczna. Mocno upolitycznione, były również towarzystwami narodowego i obywatelskiego wychowania, swoistymi instytucjami kulturalnymi. Niejednokrotnie przy „siczowych” komórkach organizowano także miejscowe zarządy Radykalnej Partii, które starały się prowadzić szerszą działalność polityczną w miejscowym środowisku ${ }^{13}$. Pomijając działalność partyjną, „Sicze" wyrabiały w społeczeństwie pożądane cechy moralne, wzajemną solidarność, dumę z przynależności do wielkiego narodu, ale także wychowywały w obowiązku złożenia ofiary, gdyby zaszła taka potrzeba. Uświadamiały konieczność walki z wyzyskiem klasowym, zaszczepiały patriotyzm i krzewiły idee niepodległego państwa ukraińskiego ${ }^{14}$. Organizowały i podtrzymywały życie towarzyskie, niosły pomoc przy gaszeniu pożarów, zakładały orkiestry, podnosiły poziom oświaty, walczyły o prawa Ukraińców i stawiały czoła plagom społecznym - pijaństwu i karcianemu hazardowi. Wspólnie wykonywane ćwiczenia wolne z nieodłącznym atrybutem siczowników - drewnianymi toporkami - na wzór stosowanych w towarzystwach sokolich, pochody, festyny, święta i siczowe pieśni działały elektryzująco na obserwatorów, przyciągając w szeregi towarzystwa wiejską młodzież ${ }^{15}$. Dla wskrzeszenia i rozpowszechnienia zaporoskich tradycji, Trylowśkyj wyróżniał zasłużonych działaczy, nadając im publicznie, na organizacyjnych świętach, imiona sławnych Zaporożców. Ciągłość z tradycją podtrzymywały także tytuły nadawane członkom zarządu każdej filii. I tak na czele każdej filii „Siczy” stał koszowy, zastępował go esauł, a w dalszej kolejności drabiny hierarchicznej byli: pisarz, skarbnik, oboźny, czterej czetarzy (od formacji zwanej czotą), chorąży, trębacz i dobosz. Jednakże tradycja i historia w towarzystwach siczowych mieszały się w bezlitosny sposób z polityką, której wpływy widoczne były nawet w organizacyjnym stroju. $\mathrm{Na}$ ośmioramiennej gwiazdce przytwierdzającej pióro do czapki siczowników, obok centralnie umieszczonego motywu dwóch dłoni trzymających sierp (symbolu chłopskich rąk) były obowiązkowo umieszczone litery „PП” (RP), co wskazywało na silne i jednoznaczne powiązanie z Radykalną Partią.

Gimnastyczny charakter „Siczy”, związek z tradycjami dawnego siczowego wojska, które przez wieki stało na straży wolności i niezależności Ukrainy, wyraźne inklinacje polityczne i związane $\mathrm{z}$ tym radykalne poglądy liderów nadawały towarzystwu z wolna cech militarnych. Wojskowa musztra, marsze, ćwiczenia gimnastyczne i przeciwpożarowe, bezwzględne posłuszeństwo wybranej starszyźnie, dyscyplina, stopnie w hierarchii żywcem wzięte od dawnego wojska zaporoskiego, historyczne i nowe pieśni, wspomniany huculski toporek jako element uzbroje-

13 R. Tomczyk, Z dziejów Ukraińskiego Ruchu Paramilitarnego w Galicji, Towarzystwo Gimnastyczne i Straży Ogniowej „Sicz”, „Przegląd Zachodniopomorski”, t. XXIV (LIII), z. 4, Rozprawy i Studia, Szczecin 2009, s. 135.

14 Ibidem, s. 131.

15 Siczowe święta były swego rodzaju odpowiednikiem zlotów sokilskich. Pierwsze centralne święto siczowe odbyło się w Kołomyi w 1902 r., dwa lata po założeniu pierwszej "Siczy”. Drugie również w Kołomyi - 28 czerwca 1903 r.; trzecie w Stanisławowie w lipcu 1904; czwarte w Kołomyi - 12 lipca 1906; piąte w Stanisławowie - w maju 1910; szóste w Śniatyniu 12 lipca 1912 r. Oprócz nich odbyły się dwa Wielkie Siczowe Zloty: 31 maja 1909 r. w Kołomyi - poświęcony pamięci hetmana Mazepy i 200. rocznicy bitwy pod Połtawą oraz wspólny z „Sokiłem” Wielki Krajowy Zlot Szewczenkowski w czerwcu 1914 r. Poza tym organizowano szereg mniejszej rangi zlotów powiatowych. 
nia, siczowe odznaki, elementy stroju (kapelusz lub czapka z czerwonym piórem), kolorowe szarfy, sztandary i jasno określeni przez liderów partyjnych wrogowie narodu w sposób jednoznaczny kształtowały profil towarzystwa ${ }^{16}$.

Radykalna „Sicz”, oparta na demokratycznych zasadach, wybierała członków swojej starszyzny, po uprzednim dokładnym ich sprawdzeniu pod kątem „politycznej przydatności”. Głównymi zasadami wyznawanymi w „Siczy” były: 1) równość i braterstwo, 2) jedność, 3) moralność, honor i szacunek dla swojej i cudzej godności, 4) wolność sumienia - w sprawie religii antyklerykalna „Sicz” pozostawiała to „sumieniu każdego członka” ${ }^{17}$. Wzorem dawnych kozaków członkowie nazywali siebie nawzajem „towarzyszami”. „Sicz” miała być ich matką, a „Wełyky Łuh” [Wielki Step] ojcem. Od samego początku ruch siczowy skierowany był do najprostszych i najbiedniejszych warstw społeczeństwa i bardzo szybko nabrał wśród ukraińskiego chłopstwa masowego charakteru ${ }^{18}$.

W przeciwieństwie do towarzystwa „Sokił”, opartego na wartościach narodowo-słowiańskich, „Sicz” hołdowała tylko i wyłącznie elementom rdzennie narodowym. Z tego powodu była dla wielu zwykłych, prostych ludzi czymś bliskim, tym, z czym mógł się identyfikować każdy Ukrainiec. Podobnie jak „Sokił”, radykalne „Sicze" wprowadziły szkolenia przeciwpożarowe i wspomagającą je szeroko zakrojoną pożarniczą propagandę. Okazało się to trafnym posunięciem, które przyciągnęło do towarzystwa wielu niezdecydowanych. Co ciekawe, dla rozwoju pożarnictwa w swoich „Siczach” Trylowśkyj zaadaptował statut ochotniczych straży pożarnych jednego z założycieli „Sokiła” - Wołodymyra Ławriwskiego, ułożony na potrzeby towarzystw sokilskich i zamieszczony w kalendarzu tegoż towarzystwa na rok $1897^{19}$. Również z literatury sokilskiej Trylowśkyj wykorzystał „Prykazy do wpraw rjadowych” (Komendy do musztry), autorstwa Ławriwskiego, zamieszczone w kalendarzu sokilskim na rok $1895^{20}$.

Od 1900 r., tj. od chwili powstania pierwszego towarzystwa siczowego do roku 1910 nieformalne centrum ruchu mieściło się w Kołomyi, w miejscu zamieszkania Trylowśkiego. Nieformalne, gdyż pierwsze powstające towarzystwa działały na podstawie indywidualnych statutów i nie utrzymywały ze sobą organizacyjnej łączności. Ruchowi brakowało organu koordynującego prace całego stowarzyszenia. W tym celu 19 kwietnia 1908 r., w Stanisławowie, założono „Hołownyj Komitet Siczowy” [Główny Komitet Siczowy (GKS)] i siczowe centrum wydawnicze ${ }^{21}$. Drukowano w nim organizacyjne pisma, a przede wszystkim, co charakterystyczne dla tej organizacji,

16 Sztandary i wszystkie elementy stroju siczowników musiały opierać się na tradycji świeckiej. 0 sztandarach m.in. pisano: Jeśli ktokolwiek zechce mieć na sztandarze jakiegoś świętego to niechaj go maluje na choragwi cerkiewnej, a nie na siczowym sztandarze. [...] na siczowych sztandarach maja być nasi narodowi bohaterowie i nasz siczowy znak, jasna siczowa gwiazda, która prowadzi nasze Sicze naprzód, do boju z nieprawdq i ciemnotą. Cyt. za: Zaporożec, Kałendar dla naroda na rik zwyczajnyj 1911, Kołomyja 1910, s. 161.

17 B. Trofymiak, Himnastyczno-sportywni orhanizaciji..., s. 219.

18 CDIAUL, F. 312, op. I, spr. 169.

19 Zasnowujte Siczy, „Hromadśkyj Hołos”, nr 19, 8 maja 1901, s. 3.

20 S. Hajduczok, Piw stolittia sokilśkych wydań, Lwiw 1937, s. 3.

${ }^{21}$ Hej, tam na hori „Sicz” ide! Propamjatna knyha „Siczej”, zibraw i uporiadkuwaw Petro Trylowśkyj, Edmonton 1965, s. 23; Zaporożec. Kałendar dla naroda na rik zwyczajnyj 1921, Wideń 1920, s. 38. 
śpiewniki. Mimo, że GKS i centrum wydawnicze powołano do życia w Stanisławowie, siedzibę miały w Kołomyi. Z początkiem roku 1910, wraz ze zmianą miejsca zamieszkania Trylowśkiego, centrum siczowe przeniosło się do miasteczka Jabłonowo ${ }^{22}$. Komitet „siczowy” koordynował działalność własnych towarzystw w Galicji Wschodniej oraz na Bukowinie, organizował festyny ludowe i święta „siczowe”, podczas których prezentowano sprawność organizacji, wyszkolenie przeciwpożarowe oraz cieszące się dużą popularnością ćwiczenia zespołowe i musztrę wojskową.

Od momentu powstania pierwszej „Siczy”, z każdym rokiem działalności zakres terytorialny stowarzyszenia się powiększał. Samo słowo „Sicz” poruszało ukraińskie społeczeństwo, wywołując w nim nieznane wcześniej odczucia. Najbardziej dynamicznym okresem rozwoju towarzystwa były lata 1903 i 1904. Wówczas powstało ponad dwieście filii, a etap ten określono nawet „rozwojowym pochodem nowoczesnego kozactwa" 23 .

Jednakże wzrost napięcia w Rosji, wybuch wojny rosyjsko-japońskiej, eskalacja tendencji rewolucyjnych sprawiły, że w konsekwencji dynamicznego rozwoju „Siczy” i w Galicji Wschodniej zaczął narastać konflikt polsko-ukraiński. Coraz częściej przeprowadzane ćwiczenia paramilitarne dla członków organizacji, elementy umundurowania, przemarsze „siczowników”, zwyczaj grupowego chodzenia w rynsztunku na niedzielne nabożeństwa, zaczęły budzić niepokój i skłaniały do jednoznacznych skojarzeń $^{24}$. Nie uszło to uwadze namiestnika Galicji, hrabiego Andrzeja Potockiego, który w „Siczach” dostrzegał zagrożenie w postaci rodzącego się pod hasłami krzewienia ruchu narodowego - ukraińskiego nacjonalizmu. Skutkiem tego zabronił on propagowania siczowych idei, a także przeprowadzania siczowych świąt i noszenia wszelkich oznak z nimi związanych. Zamiast „Siczy”, w której widział również ostoję chłopskiego socjalizmu, sugerował ludności ukraińskiej zakładanie czytelni „Proswity”, ewentualnie filii „Sokiła”25. Licząc na ukrócenie działalności organizacji „siczowych", wydał okólnik skierowany do starostów powiatów wschodniogalicyjskich, by ci uważnie przyjrzeli się paramilitarnym ćwiczeniom „Siczy”. Mieli oni obserwować, czy w ich trakcie wdrażano musztrę wojskową lub czy używano huculskich toporków. Pismo namiestnika dało starostom prawomocny oręż do walki z tą ukraińską organizacją. Na jego podstawie zaczęto wprowadzać restrykcje i utrudnienia dla działalności „Siczy”, dlatego rok 1905 przyniósł nieznaczny zastój siczowego rozwoju. Ale atmosfera polityczna pierwszej dekady XX w. w Galicji Wschodniej wciąż się zaogniała, a wzburzenie ludności ukraińskiej narastało. Otwarcie nawoływano do fizycznej rozprawy z przeciwnikami. Dodatkowo, narodowcy ukraińscy zaczęli obwiniać namiestnika Potockiego za klęskę wyborczą ${ }^{26}$, stawiając go jako symbol

22 B.I. Kowerko, Sokilśkyj i siczowyj himnastycznyj ruch..., s. 71.

23 J. Lubyżanin, O. Ulitin, M. Nahorniuk, Do pytannia istoriji „Sokilśkich" ta „Siczowych" periodycznych wydań (do 1914 r.), „Pedahohika, Psychołohija ta Medyko-Biołohiczni Problemy Fizycznoho Wychowannia i Sportu", nr 15, Specjalnyj wypusk za temoju: Tradyciji Ukrajinśkoji Fizycznoji Kultury i Formuwannia Systemy Fizycznoho Wychowannia w Ukrajini, czastyna I, Charkiw-Lwiw 2003, s. 63.

24 R. Tomczyk, Z dziejów Ukraińskiego Ruchu Paramilitarnego w Galicji..., s. 138.

25 R. Tomczyk, Z dziejów Ukraińskiego Ruchu Paramilitarnego..., s. 142.

${ }^{26}$ Pod wpływem rosnącej opozycji Potocki zdecydował się udzielić poparcia moskalofilom. W przeprowadzonych w lutym 1908 r. wyborach do Sejmu, Ukraińcy wprawdzie uzyskali 21 mandatów, ale 10 z nich przypadło „starorusinom”, co doprowadziło do sporej dyspro- 
wielowiekowego ucisku i niesprawiedliwego panowania szlachty polskiej nad Ukraińcami. W niechęci Potockiego do „Siczy” upatrywano także pobudek osobistych - zamiaru odpłacenia się za krzywdy rodu doznane od kozackich oddziałów siczowych w trakcie powstań na Ukrainie w XVII w. Finałem tych nastrojów, 12 kwietnia 1908 r., był udany zamach na namiestnika. Zbrodnia ta sprowadziła na towarzystwa siczowe falę represji i aresztowań, tym bardziej, że zamachowca - Myrosława Siczynśkiego podejrzewano o sympatyzowanie z siczowymi ideami ${ }^{27}$. Następca Potockiego, namiestnik Michał Bobrzyński, utrzymując kurs poprzednika, polecił starostom zaostrzenie działań administracyjnych. W tajnym liście - rozporządzeniu z 25 maja 1908 roku - w terminie do 8 dni, Prezydium Namiestnictwa we Lwowie wymogło na wszystkich starostwach Wschodniej Galicji przygotowanie i złożenie szczegółowych raportów dotyczących stanu i rozwoju „Siczy” w poszczególnych powiatach, dotyczących liczby towarzystw i porównania ich dynamiki z poprzednimi latami. Proszono także o niezwłoczne nadesłanie odpowiedzi na pytania: Czy towarzystwa „siczowe” są aktywne? Czy ich organizowane występy, zloty i festyny noszą radykalny, nacjonalistyczny, rewolucyjny, a tym samym antypaństwowy charakter? Czy ich działalność gimnastyczna nie jest przykryciem dla polityczno-rewolucyjnych tendencji? Czy noszenie odznak, stroju siczowego i szarf jest związane ze świętem, czy nosi się je także w dzień powszedni? Czy za demonstracyjne noszenie siczowych wyróżników noszący je byli przez starostę karani czy też nie? ${ }^{28}$

Jak widać z zamieszczonej poniżej Tabeli 1, pomimo czynionych przez władze formalnych utrudnień, nie przeszkodziły one zbytnio w dalszym progresie ukraińskiej organizacji. Więcej, represje nie mogły być na tyle dotkliwe, gdyż kierownictwo siczowe jako przyczynę niedostatecznego rozwoju organizacji w tym okresie wskazywało na szkodliwą działalność pastuchów dusz naszych (jak pejoratywnie określano w siczowych kręgach - popów moskalofilów) oraz Żydów rozpijających chłopów, którym: nie w smak była siczowa polityka, a nie na prześladowania i represje ze strony aparatu państwa ${ }^{29}$.

porcji wpływów. Poparcie stronnictwa moskalofilów w kręgach ukraińskich narodowców potraktowano jako prowokację. Zob.: J. Wiśnicki, Sprawa ukraińska jako element walki politycznej między konserwatystami a narodowa demokracją w Galicji przed I wojnq światową, „Annales Universitatis Mariae Curie-Skłodowska Lublin - Polonia”, vol. I, sectio F, Lublin 1995, s. 228; C. Partacz, Od Badeniego do Potockiego. Stosunki polsko-ukraińskie w Galicji w latach 1888-1908, Toruń 1996, s. 220.

27 Siczynśkyj należał do „Siczy”, ale nie do towarzystwa gimnastyczno-pożarniczego, a jedynie do korporacji studenckiej o takiej samej nazwie, działającej od roku 1864 przy Uniwersytecie w Wiedniu. Z. Kuzela, M. Czajkeskyj, 1868-1908 „Sicz”. Almanach w pamjat' 40-ych rokowyn zasnuwannia Towarystwa "Sicz” u Widnji, Lwiw 1908.

28 Poza tym rozporządzeniem rozpoczęły się aresztowania co bardziej aktywnych siczowych działaczy. Nie pozostawiono w spokoju założyciela i głównego atamana „Siczy”, posła na Sejm Kyryła Trylowśkiego. Ponadto władze zabroniły używania wszelkich atrybutów związanych z towarzystwem „Sicz”. Grożono również całkowitym zlikwidowaniem związku siczowego. Zob.: B. Trofymiak, Himnastyczno-sportywni orhanizaciji..., s. 247-248.

29 Ibidem, s. 251. 
Tabela 1. Dynamika powstawania towarzystw „Siczowych” w Galicji w latach 1900-1914

\begin{tabular}{|c|c|c|}
\hline Rok & $\begin{array}{c}\text { Liczba towarzystw „Siczowych” } \\
\text { założonych w poszczególnych latach }\end{array}$ & $\begin{array}{c}\text { Liczba towarzystw „Siczowych” } \\
\text { razem }\end{array}$ \\
\hline 1900 & 1 & 1 \\
\hline 1901 & 1 & 2 \\
\hline 1902 & 4 & 6 \\
\hline 1903 & 104 & 228 \\
\hline 1904 & 118 & 261 \\
\hline 1905 & 33 & 336 \\
\hline 1906 & 75 & 426 \\
\hline 1907 & 90 & 540 \\
\hline 1908 & 114 & 617 \\
\hline 1909 & 77 & 724 \\
\hline 1910 & 107 & 792 \\
\hline 1911 & 68 & $<823^{*}$ \\
\hline 1912 & 31 (dane do czerwca 1912) & $\approx 794^{*}$ \\
\hline 1913 & b.d. & $\approx 813^{*}$ \\
\hline 1914 & b.d. & \\
\hline
\end{tabular}

*Dokładne dane co do liczby swoich towarzystw „siczowe” źródła podają do połowy 1912 r. Liczba towarzystw w latach 1912-1914 została oszacowana w oparciu o uśrednione, rozbieżne opracowania badaczy ukraińskich.

Źródło: „Siczowy Wisty” nr 1, styczeń 1913, s. 8-9; Atlas Ukrajiny i sumeżnych krajiw, Lwiw 1937, s. XLVIII, tab. nr 14, 140. B. Trofymiak, Himnastyczno-sportywni orhanizaciji.., s. 232;

0. Waceba, Narysy z istoriji zachidno-ukrajinśkoho sportywnoho ruchu, Iwano-Frankiwsk 1997, s. 138.

Tabela 2. Dynamika powstawania towarzystw „Siczowych” w poszczególnych powiatach Galicji w latach 1900-1913

\begin{tabular}{|c|c|c|c|c|c|c|c|c|c|c|c|c|c|c|}
\hline Powiat* & 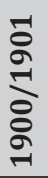 & 옹 & ஜ̊ & ஓั & 농 & ஜ욤 & 용 & $\begin{array}{l}\infty \\
\stackrel{2}{\circ} \\
\stackrel{-}{-1}\end{array}$ & ஓ̊ & 음 & ने & 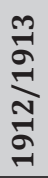 & 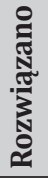 & $\frac{1}{0}$ \\
\hline Brzeżany & & & 4 & 1 & - & 1 & 2 & 1 & 1 & 6 & 2 & 1 & - & 19 \\
\hline Bóbrka & & & - & - & - & 2 & 5 & 6 & 4 & 9 & 4 & - & - & 30 \\
\hline Bohorodczany & & & 3 & 2 & 4 & 10 & - & 1 & - & - & - & - & - & 20 \\
\hline Borszczów & & & 1 & 2 & - & - & 1 & 1 & 1 & 5 & 8 & 3 & - & 22 \\
\hline Brody & & & - & - & - & 2 & - & - & - & 1 & 3 & - & - & 6 \\
\hline Buczacz & & & - & 2 & 1 & 3 & 1 & 13 & 6 & 6 & 1 & - & 1 & 32 \\
\hline Horodenka & & 1 & 7 & 2 & - & 4 & 2 & 1 & 2 & 1 & 10 & 3 & - & 33 \\
\hline Gródek & & & - & - & - & - & - & - & - & - & - & - & - & - \\
\hline
\end{tabular}




\begin{tabular}{|c|c|c|c|c|c|c|c|c|c|c|c|c|c|c|}
\hline Powiat* & 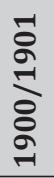 & 옹 & ๓̊ & ণ্ণ & 농 & ஜ̊ & 용 & $\begin{array}{l}\infty \\
\stackrel{\circ}{\circ} \\
\stackrel{-}{-1}\end{array}$ & ஓ̊ & $\stackrel{\circ}{\stackrel{0}{\sigma}} \underset{-1}{-1}$ & ने & $\begin{array}{c}\text { n} \\
\stackrel{\sigma}{\sigma} \\
\underset{\sigma}{\sigma} \\
\frac{\sigma}{\sigma}\end{array}$ & 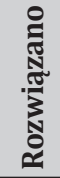 & $\frac{\Xi}{0}$ \\
\hline Husiatyn & & & - & 1 & - & 1 & 4 & 4 & 2 & - & - & - & - & 12 \\
\hline Dobromil & & & - & - & - & - & - & - & - & 1 & 3 & 2 & - & 6 \\
\hline Dolina & & & 1 & - & - & 1 & 6 & 7 & 1 & 1 & - & - & - & 17 \\
\hline Drohobycz & & & - & - & 1 & 3 & - & 9 & 2 & 2 & 1 & - & - & 18 \\
\hline Żydaczów & & & 2 & - & - & - & - & 1 & 1 & 1 & 1 & 1 & - & 7 \\
\hline Żółkiew & & & - & - & - & - & - & - & - & 1 & - & - & - & 1 \\
\hline Zaleszczyki & & & - & - & 2 & 2 & 5 & - & 1 & 4 & 4 & - & - & 18 \\
\hline Zbaraż & & & - & 1 & 1 & - & - & 2 & - & 1 & 1 & 8 & - & 14 \\
\hline Zborów & & & - & - & - & - & 2 & 2 & 1 & - & 2 & - & - & 7 \\
\hline Złoczów & & & - & 1 & - & - & - & - & 1 & 2 & 1 & - & - & 5 \\
\hline Kałusz & & & 3 & 1 & - & 4 & 8 & 2 & - & - & - & - & - & 18 \\
\hline $\begin{array}{l}\text { Kamionka } \\
\text { Strumiłowa }\end{array}$ & & & - & 1 & - & - & - & - & 2 & 2 & - & - & - & 5 \\
\hline Kołomyja & 1 & & 13 & 13 & 3 & 10 & 6 & 2 & 4 & 1 & - & - & 2 & 51 \\
\hline Kosów & & & 10 & 37 & 3 & 2 & 6 & 1 & 1 & 4 & 2 & - & 20 & 46 \\
\hline Lwów & & & 1 & 1 & 1 & - & - & 2 & 1 & 5 & - & - & 1 & 10 \\
\hline Mościska & & & - & 1 & - & - & 3 & 3 & 1 & 1 & 5 & - & - & 14 \\
\hline Nadwórna & & & 1 & 7 & 5 & 11 & 1 & 2 & 1 & - & - & - & - & 28 \\
\hline Nowy Sącz & & & - & - & - & - & - & - & - & 1 & - & - & - & 1 \\
\hline Przemyśl & & & - & 1 & 4 & 2 & - & - & 2 & 8 & 1 & 1 & - & 19 \\
\hline Przemyślany & & & - & - & - & - & 4 & - & - & 4 & - & - & - & 8 \\
\hline Peczeniżyn & & & 3 & 6 & 3 & 1 & 4 & 5 & - & 2 & 1 & - & 3 & 22 \\
\hline Podhajce & & & - & - & - & 4 & 9 & 4 & 1 & 1 & - & 1 & - & 20 \\
\hline Rawa Ruska & & & 1 & - & - & - & - & - & - & - & - & - & - & 1 \\
\hline Rohatyn & & & 2 & 2 & - & - & 3 & 2 & 8 & 6 & 3 & 2 & - & 28 \\
\hline Rudki & & & - & - & - & - & - & 1 & 1 & 1 & 1 & 2 & - & 6 \\
\hline Sambor & & & - & - & 1 & - & - & 6 & 2 & - & 2 & 1 & - & 12 \\
\hline Skałat & & & - & - & - & - & - & - & 4 & 2 & - & 1 & - & 7 \\
\hline Śniatyń & 1 & 3 & 24 & 9 & 1 & 1 & 1 & 4 & 3 & 2 & 3 & 1 & 1 & 52 \\
\hline Sokal & & & 7 & 1 & - & 2 & 1 & 2 & 4 & 4 & - & - & - & 21 \\
\hline Stanisławów & & & 15 & 16 & - & 3 & 3 & 8 & - & 5 & - & 1 & 1 & 50 \\
\hline Stary Sambor & & & - & - & - & 1 & - & - & - & - & - & - & - & 1 \\
\hline Stryj & & & - & - & 1 & 1 & 3 & 1 & 8 & 5 & - & - & - & 19 \\
\hline Sanok & & & - & - & - & - & - & - & - & - & - & - & - & - \\
\hline Trembowla & & & 1 & 1 & - & - & 3 & 2 & 1 & 1 & 1 & - & - & 10 \\
\hline Tarnopol & & & 2 & 5 & - & - & - & 4 & 2 & 1 & 6 & 1 & - & 21 \\
\hline Tłumacz & & & 3 & 3 & - & 2 & 4 & 12 & 7 & 5 & 1 & 1 & - & 38 \\
\hline Turka & & & - & - & - & - & 1 & - & 1 & 1 & - & - & - & 3 \\
\hline Cieszanów & & & - & - & 1 & - & 1 & - & - & - & - & 1 & - & 3 \\
\hline Czortków & & & - & 1 & 1 & 2 & - & 1 & - & 3 & - & - & - & 8 \\
\hline Jaworów & & & - & - & - & - & 1 & 2 & - & 1 & 1 & - & - & 5 \\
\hline Ogółem & 2 & 4 & 104 & 118 & 33 & 75 & 90 & 114 & 77 & 107 & 68 & 31 & 29 & 794 \\
\hline
\end{tabular}

*Powiaty wymieniono w porządku alfabetycznym języka ukraińskiego.

Źródło: „Siczowy Wisty”, Rik II, nr 1, styczeń 1913, s. 8-9. 
Trudną do zrozumienia była nienawiść Trylowśkiego do wiary i do kleru, który nazywał „skórozdziercami”, tym bardziej, że on sam pochodził z rodziny duchownego, zawdzięczając mu m.in. swoje wykształcenie. I chociaż „Siczowy Batko”, jak zwano Trylowśkiego, na każdym kroku manifestował niechęć do duchowieństwa, to jak sam zaznaczał: nigdy nie występował przeciw religii..., chciałem tylko tego, by „Sicze” nie miały klerykalnej opieki. Kto chciał ja mieć, miał ja $w$ „Sokołach" ${ }^{\text {"30. }}$.

Jednak w jego działalności politycznej antyklerykalnych wystąpień można było doszukać się znacznie więcej, jak choćby składanie daleko idących obietnic bez pokrycia w imieniu Radykalnej Partii - bez żadnego upoważnienia ze strony jej kierownictwa - które miały dotyczyć nadań ziemi dla chłopów aktywnie przeciwstawiających się popom. Co najmniej tak, jakby od unicestwienia Cerkwi miały zależeć przyszłość i szczęście Ukrainy.

Antyklerykalizm Trylowśkiego ostrej krytyce poddał podczas spotkania w Domu Narodowym w roku 1913 sam Iwan Franko, ukraiński poeta i pisarz, jeden ze współzałożycieli Radykalnej Partii. Tuż po wystąpieniu Trylowśkiego powiedział: Do pomyłek jakie w życiu zrobiłem, należy moja praca przy kładzeniu podwalin Radykalnej Partii. Rozwój tej partii dał możliwość demagogom podobnym jak mój przedmówca Trylowśki. Nieszczęściem naszego narodu jest to, że partia, dla której podwaliny kładłem zabroniła narodowej duszy i chrześcijańskiego światopoglądu. Nasza młodzież nie zna Pisma Świętego - uważa go za niepotrzebne do czytania. Kiedy mógłbym wam dać jakąś radę na przyszłość, szczególnie młodym, to radziłbym wam częstsze spowiadanie się i przystępowanie do świętych Sakramentów, by w ten sposób zbliżyć się do Boga ${ }^{31}$.

Przeniesiony na grunt siczowy i praktykowany tam ateizm pozwolił ukuć „sokilskim” działaczom sarkastyczne porównanie dawnej tradycji Siczy Zaporoskiej do organizacji zaproponowanej przez Trylowśkiego: Na dawnej Siczy była cerkiew i był pop, nie było kobiet. Radykalna Sicz nie uznaje cerkwi, nie dopuszcza do siebie popa, dopuszcza kobiety ${ }^{32}$.

Abstrahując od antyklerykalizmu, pragnieniem kierownictwa i zwolenników ruchu siczowego było stałe wzmacnianie poszczególnych towarzystw i scentralizowanie wszystkich istniejących i rozsianych na dużym obszarze organizacji. W tym celu Główny Komitet Siczowy zwołał do Lwowa, na dzień 4 grudnia 1912 r., Krajowy Zjazd Siczy. Wzięli w nim udział delegaci organizacji z całego kraju. W czasie tego zjazdu podjęto uchwałę o powołaniu Ukrajinśkieho Siczowoho Sojuzu [Ukraińskiego Związku Siczowego - (USS)]. Nowy związek objął patronatem wszystkie siczowe towarzystwa, oparte na świeckim fundamencie. Zastrzeżono przy tym, że członkiem tych towarzystw mógł zostać tylko Ukrainiec lub Ukrainka, również stanu świeckiego ${ }^{33}$.

${ }^{30}$ Hej, tam na hori „Sicz” ide!.., s. 60.

31 B. Trofymjak, Himnastyczno-sportywni orhanizaciji..., s. 216; „Swoboda” z 28 lipca 1995.

32 T. Franko, Istorija i teorija ruchanky, Kołomyja-Lwiw 1923, s. 74.

33 Zastrzeżenie o świeckości miało być również wyróżnikiem radykalnych towarzystw siczowych, gdyż obok nich, od roku 1908, zaczęły powstawać filie „Sokiła”, którym organizacja pozwoliła na przyjmowanie nazwy „Sicz”, co było nie do zaakceptowania przez radykałów. Sokilskie "Sicze” miały stanowić pomost łączący obie centrale w jeden przyszły wspólny związek. Tak przynajmniej zakładali działacze „Sokiła”, którzy udostępnienie tej nazwy swoim filiom motywowali w sposób następujący: Pozostawiamy swoim filiom pewna samodzielność, tak że każda filia może sobie nadać nazwę jaka jej jest ulubiona. I tak mogq 
Na czele związku stanęła Generalna Starszyzna w składzie: Kyrył Trylowśkyj - generalny ataman; Jarosław Wesełowśki - generalny esauł; Mykoła Bałyćki - generalny pisarz; Sydir Wynnykiw - generalny skarbnik; Dmytro Katamaj - generalny oboźny, a od 1913 r. szef sekcji strzeleckiej; Fedir Kałynowycz - generalny czetar ${ }^{34}$. Zadaniem USS było utrzymanie jedności siczowego ruchu, jego kontroli i niesienie pomocy we wszelkich przejawach działalności towarzystw. Równocześnie z powstaniem Ukraińskiego Związku Siczowego w 1912 r. utworzono jego lwowską centralę. Na zjeździe delegaci przyjęli następującą strukturę związku:

Najwyższym organem USS został Krajowy Zjazd Siczowy. Zwoływała go, co najmniej raz na trzy lata, Generalna Siczowa Starszyzna. Ustalała ona także miejsce zjazdu. Każda „Sicz” miała prawo wysłać na zjazd dwóch delegatów zaopatrzonych w organizacyjne legitymacje. Oprócz nich w zjeździe brał udział każdy powiatowy koszowy względnie esauł.

W hierarchicznej kolejności następną była Krajowa Rada Siczowa. Jej skład tworzyli powiatowi atamani i członkowie Generalnej Starszyzny. Krajowa Rada Siczowa zbierała się raz do roku, w jesieni. Sporządzała sprawozdania z działalności ruchu siczowego, układała plany dalszej siczowej pracy i przygotowywała wybory Generalnej Siczowej Starszyzny. Z kolei Krajową Radę Siczową zwoływała wybierana przez nią Generalna Siczowa Starszyzna. W razie zaistnienia spraw wielkiej wagi Generalna Siczowa Starszyzna mogła zwołać nadzwyczajne zebranie Krajowej Rady Siczowej.

W skład Generalnej Siczowej Starszyzny wchodzili: 1) Generalny Ataman, 2) Generalny Esauł, 3) Generalny Pisarz, 4) Generalny Skarbnik, 5) Generalny Oboźny, 6) dwóch Generalnych Czetarów i dwóch ich zastępców. Generalna Siczowa Starszyzna wykonywała zadania Ukraińskiego Związku Siczowego. Przyjmowała do Związku pojedyncze organizacje siczowe lub je wykluczała. Generalną Siczową Starszyznę wybierano każdej jesieni na okres jednego roku. Generalna Siczowa Starszyzna miała prawo do powoływania sekcji. Każda sekcja składała się z dowolnej liczby członków, ale nie mogło ich być mniej niż trzech.

W powiecie najwyższą siczową władzę stanowiła Powiatowa Sicz sprawująca pieczę, średnio, nad 20 siczowymi filiami. Reprezentowała ją Powiatowa Rada Siczowa, składająca się ze wszystkich koszowych z danego powiatu ${ }^{35}$. Spośród nich wyłaniano dziewięcioosobową Powiatową Siczową Starszyznę: powiatowego atamana, esauła, pisarza, skarbnika, oboźnego i czterech powiatowych czetarów ${ }^{36}$.

być sokilskie filie nazywane imieniem świętych, imieniem naszych wybitnych pisarzy i działaczy narodowych, a także pod chwalebnq i drogq nam wszystkim historycznq nazwq "Sicz”. Uwzględniając i poważając niezależność każdej organizacji „Sokił” wcale nie ma na celu przeciagania "Siczy” [radykalnych] tym sposobem. "Sokił” idzie otwarta, uczciwq droga i dlatego też z jego łona wyszedł projekt, by założyć „Zwiq̨zek Gimnastycznych i Pożarniczych Towarzystw" na wzór zjednoczenia takich towarzystw w Serbii. Do tego zwiq̨zku należałyby zarówno Sokiły jak i Sicze [radykalne] i ten związek objąłby dzieło organizacji połaczenia i kontroli pożarniczych Sokiłów i Siczy, bo ta praca obecnie jest ponad siły lwowskiego Sokiła, a wśród Siczy nie posiadających jednomyślnej organizacji jest dosyć zaniedbana. Cyt. za: „Sokilśky Wisty”, nr 3, 17 września 1908, s. 1; „Siczowy Wisty”, nr 1, styczeń 1913, s. 1.

34 Hej, tam na hori „Sicz” ide!..., s. 175.

35 I. Andruchiw, Ukrajinśki mołodiżni towarystwa Hałyczyny: 1861-1939 rr. (Korotkyj istorycznyj narys), Iwano-Frankiwśk 1995, s. 17.

36 „Siczowy Wisty”, nr 2 i 3, luty-marzec 1913, s. 19-22. 
Podstawą majątku związku były składki członkowskie. Każda „Sicz” była zobowiązana do przekazania związkowej kasie co najmniej 2 korony rocznie, a każdy siczownik wpłacał na konto swojego macierzystego towarzystwa 1 koronę i 20 centów. W kwocie tej była zawarta prenumerata siczowego organu „Siczowy Wisty”37.

Historyczną zasługą „Siczy” było to, że jej towarzystwa przygotowywały naród do wydarzeń, w których mogła brać udział tylko wychowana, solidarna i narodowo świadoma nacja. Znalazło to m.in. potwierdzenie w przededniu I wojny światowej, kiedy konflikt zbrojny między Rosją a państwami centralnymi wydawał się być nieuchronnym. Wówczas od Ukraińskiego Związku Siczowego wyszła propozycja organizacji towarzystwa Ukraińskich Strzelców Siczowych - przyszłych żołnierzy mających walczyć o wolność Ukrainy.

Statut towarzystwa strzeleckiego składany przez Związek Siczowy był dwukrotnie odrzucany przez władze. Dopiero gdy za trzecim razem lider „Siczy” - Trylowśkyj przełożył słowo w słowo statut polskiego „Strzelca”, władze nie miały już żadnego argumentu by po raz kolejny go odrzucić - inaczej musiałyby również zabronić działalności polskiemu towarzystwu ${ }^{38}$. Tym sposobem 18 marca 1913 r. we Lwowie oficjalnie doszło do założenia pierwszego ukraińskiego towarzystwa strzeleckiego o nazwie: „Siczowi Strzelcy" ${ }^{39}$. W ramach wojskowego szkolenia Związek Siczowy organizował szereg zajęć z zakresu nauki strzelania i manewrów polowych. Wiele z nich Trylowśkyj doglądał osobiście. Między innymi był obecny w kwietniu na dużych manewrach w podlwowskim Kajzerwaldzie, a 28 czerwca 1914 r. na Zlocie Szewczenkowskim sam dowodził oddziałami „Siczy”. W przededniu zlotu, 27 czerwca, Trylowśkyj wygłosił przemówienie, w którym wskazał na święty obowiązek wyzwolenia „Kobzarowej” (od dzieła Kobziarz Tarasa Szewczenki) mogiły i uwolnienia ukraińskiego narodu od carskiego jarzma, podkreślając że: Może już niedaleka ta chwila, kiedy przyjdzie nam naostrzyć bagnety karabinów naszych na kamieniu tarasowej mogiły ${ }^{40}$. Z chwilą wybuchu I wojny światowej Trylowśkyj został „hołową” sekcji organizacji „Bojewoji Uprawy” [Zarządu (Sztabu) Wojskowego] Legionu Ukraińskich Siczowych Strzelców.

Chociaż ruch siczowy miał wielki wpływ na kształtowanie świadomości i zmysłu organizacyjnego wśród mas, to w oczach oponentów był prowadzony zbyt powierzchownie. W porównaniu z podobnymi sokilskimi towarzystwami, postrzegano go - niesprawiedliwie zresztą - jako nastawiony przede wszystkim na blichtr, rozgłos, pokaz i „fanfaronadę”.

Zarówno siczowy, jak i sokilski ruch wzięły początek z niewielkich pojedynczych towarzystw i w stosunkowo krótkim czasie rozrosły się w wielkie i szeroko rozgałęzione organizacje. „Sokił-Batko” (Ojciec) i „Sicz” (Macierz) miały szansę stać się wielką państwotwórczą siłą, ale pod warunkiem, że we wspólnym interesie połączą się w proponowany przez działaczy sokilskich jeden wspólny, potężny organizm. Na

37 Pismo związku „Siczowy Wisty” wychodziło pierwotnie w roku 1912 przy „Hromadśkim Hołosie”, a od roku 1913 ukazywało się samodzielnie. Jego redaktorem był Dmytro Katamaj. Po wojnie ukazywało się w latach 1922-1924. Ukrajinśki Czasopysy Lwowa 1848-1939, t. II: 1901-1919, red. M.M. Romaniuk, Lwiw 2002, s. 459.

38 K. Trylowśkyj, Moja znajomość z Józefem Piłsudskim, „Niepodległość” 8(1933), z. 3, s. 444.

39 I. Krypiakewycz, B. Hnatewycz, Z. Stefaniw, O. Dumin, S. Szramczenko, Istorija Ukrajinśkoho Wijśka, t. II, Kyjiw 1995, s. 7.

40 CDIAUL, F. 146, op. VIII, spr. 1040, s. 23. 
drodze zjednoczenia stanęło przede wszystkim zbyt duże upolitycznienie „Siczy”, jej zależność od Radykalnej Partii, odrzucenie wartości chrześcijańskich, które dla wielu Ukraińców było nie do przyjęcia, czy wreszcie wodzowskie aspiracje „Siczowego Batki” i jego niechęć do zawierania kompromisów. Wydawać by się mogło, iż tym dwóm organizacjom chodziło o to samo, jednak istniały między nimi spore rozbieżności. Różnice w rozumieniu sprawy ukraińskiej często były tak istotne, że czasem doprowadzało to do niezręcznych sytuacji, jak np. w czasie zlotu chorwackiego „Sokoła” w Zagrzebiu w dniach 13-15 sierpnia 1911 r. Gdy w imieniu każdej delegacji z poszczególnych narodowych towarzystw gimnastycznych zaproszonych na zlot przemawiał jeden przedstawiciel, ze strony Ukraińców wystąpiło dwóch: jeden reprezentujący „Główny Komitet Siczowy”, drugi „Sokiła”. Obaj wysłannicy siedzieli przy stole $\mathrm{w}$ różnych miejscach, $\mathrm{z}$ dala od siebie i, co nie uszło uwadze zebranych, obaj nieprzychylnie do siebie nastawieni ${ }^{41}$. Tworzyło to niekorzystne wrażenie, pokazując wszystkim, że Ukraińcy nawet poza granicami i w trakcie słowiańskiego święta jedności potrafią manifestować różnice wewnętrzne i własne animozje. Obrona interesów narodowych na zewnątrz wymagała tego, by w takich okolicznościach istniała jednomyślność. Ukraińcy nie mieli zgodnego kierunku działania, jednego wspólnego planu, jednej organizacji. Za to istniały dwa duże związki, a każdy z nich aspirował do tego, by zostać przewodnią siłą ukraińskiego narodu. Nie do pogodzenia był apolityczny charakter „Sokiła” z wysoce upolitycznionym charakterem „Siczy”. Choćby tylko z tej przyczyny „Sokił” nie mógł wejść w struktury „Siczy” radykalnych. Mimo to, dla dobra narodu, gotów był do programowych ustępstw w celu dokonania fuzji z radykałami i doprowadzenia do powstania wspólnego ukraińskiego związku o charakterze gimnastyczno-pożarniczym zdolnego krzewić narodowe idee. Wyprzedzając przyszłe prognozowane zjednoczenie, w „Sokile” zezwolono nowo powstającym filiom na przyjmowanie nazwy... „Sicz” ${ }^{2}$. Na to nie chcieli się zgodzić, ani nawet przyjąć tego do wiadomości siczowi liderzy z „Huculskim Batkiem” na czele. W siczowym kalendarzu „Zaporożec” pojawienie się konkurencyjnych sokilskich „Siczy” opatrzono takim oto komentarzem: Siczowa organizacja i jej naczelny zarząd „Hołownyj Komitet Siczowyj” starały się zawsze przyjaźnie odnosić do ruskich Sokiłów. Ale kiedy tak po jezuicku biorą się [Sokiły] do podkopywania siczowej organizacji i całkiem jawnie staja się orężem w rękach klerykałów, to teraz dla każdego postępowego Rusina może być tylko taka taktyka: Daleko od Sokiłów, precz z sokilskimi Siczami! $!^{43}$

W ewentualnej fuzji radykałowie obawiali się utraty wpływów zarówno w związku siczowym, jak i - co z tym się wiązało - także na arenie politycznej. Ambicje polityczne nie były jednymi, jakie leżały u podstaw różnic między oboma organizacjami. Do nich należały kultywowane tradycje, od słowiańsko-narodowych re-

${ }^{41}$ Zwracano przy tym Ukraińcom uwagę, że dostojeństwo narodu wymaga, ażeby $w$ takich sprawach istniała jednomyślność. Zob.: „Wisty z Zaporoża”, nr 68, 30 kwietnia 1912, s. 8.

42 Nadawanie nazwy „Sicz” nowym filiom „Sokiła” stało się faktem po kongresie „Proswity” w roku 1909. W jego trakcie, po jednym z referatów pt. Pożarni „Sokoły”, Kongres uznał: Ze względu na jedność i planowość akcji kongres uznaje potrzebę założenia bezpartyjnego Zwiq̨zku ukraińskich gimnastycznych i pożarniczych towarzystw, a dopóki to nie nastapi, zbliżenie i porozumienie wśród dotychczas istniejących organizacji. Zob.: Perszyj Ukrajinśkyj Proświtno-Ekonomicznyj Kongres, uładżennyj Towarystwom „Proświta” w soroklittia zasnuwannia u Lwowi. Protokoły i Referaty, red. dr I. Bryk i dr M. Kociuba, Lwiw 1910, s. 245-246.

43 Zaporożec. Kałendar dla naroda na rik zwyczajnyj 1911, Kołomyja, s. 160. 
prezentowanych przez „Sokiła”, do nacjonalistyczno-narodowych po stronie „Siczy”. Osobną była, podkreślana już w kilku miejscach, sprawa religii. Zdecydowanie antyklerykalny i ateistyczny fundament towarzystwa firmowanego przez radykałów kłócił się z zasadami opartymi na wartościach chrześcijańskich większości towarzystw, które pozwalały na piastowanie funkcji prezesów niektórych filii, w tym filii „Sokiła”, nawet duchownym greckokatolickim, na co ze zgrozą reagowali radykałowie:

...Członkami tychże [Sokilskich] „Siczy” mogli być już także i duchowni! Sokilskie „Sicze” były więc $w$ swoim duchu tożsame $z$ „Sokiłami”, różniąc się tylko formalnie nazwą! Od tego czasu zaczęła się jawna wrogość pomiędzy niezależnymi od klerykalnych wpływów „Siczami” [radykalnymi] i „Sokiłami” i ich „filiami”, jak je nazywał naród „pałamarskimi"44 Siczami ${ }^{45}$.

Zupełnie odmienne było także nastawienie do problemów gimnastyki i wychowania fizycznego w ogóle. Dla „Sokiła” była to sprawa pierwszorzędnego znaczenia. „Sokił” budował zatem sale, boiska, organizował place do ćwiczeń, masowo szkolił instruktorów, wydawał fachową literaturę sportową, podczas gdy w radykalnych „Siczach” sprawa wychowania fizycznego nie nabierała takiej wagi ${ }^{46}$. Służyła bardziej celom pokazowym, ceremoniałom, propagandzie, wyeksponowaniu siły, karności i jedności panującej w towarzystwie niż faktycznemu wychowaniu i odrodzeniu fizycznemu jednostek. Wymownym tego przykładem był pokaz sprawności obu towarzystw w roku 1910 podczas piątego święta siczowego w Stanisławowie z okazji jubileuszu dziesięciolecia istnienia „Siczy”:

Sokilscy gimnastycy stopniowali trudność swoich występów od lekkich do ciężkich, tak że każdemu nawet nie gimnastykowi przyszło na myśl, że wykonanie ich nie jest niemożliwe, a przeciwnie układ taki zachęca nawet szersze warstwy do zainteresowania się gimnastyką. Przeciwnie było u czerniowieckich siczowników. Wzięli oni ćwiczenia [do pokazów] od razu trudne i nie nadające się na to narodowe święto, ale nawet na gimnastyczny występ. Miejscem dla takich ćwiczeń jest Koloseum albo cyrk. Bardzo przykre wrażenie robiły ćwiczenia na kółkach jednego z czerniowieckich siczowników, którego siłę można było podziwiać, ale wykręcanie rąk $w$ stawach barkowych wyglądało jak średniowieczne tortury. Niesmak u widzów wywoływało kłanianie się gimnastyków po zakończeniu ćwiczeń, kiedy publiczność nagradzała ich oklaskami, tak, że miało się wrażenie, że ma się przed sobq jakiegoś cyrkowca, który różnił się chyba tylko tym, że nie posyłał jeszcze kobietom pocałunków. Również nie widać było u nich [siczowników] żadnej karności i znajomości musztry, bo kiedy wyszli do ćwiczeń i ustawili się, to jeden stał za blisko drugiego, inny znowu za daleko, jeden obracał się, inny występował z szeregu, trzeci zaś rozkładał i pokazywał rękami.

Niektórzy gimnastycy [siczowi] nie wiedzq zupełnie, co to jest porządek i dyscyplina. Jeden gimnastyk w szeregu, najbliżej trybuny wyciaga tytoń, skręca cygaretkę i spokojnie pali nawet podczas komendy „baczność” i kiedy przewodnik pokazywał ćwiczenia ${ }^{47}$.

Również w obszarze budowy zaplecza sportowego i szkolenia instruktorów „Sicze” pozostawiały wiele do życzenia. Choćby tylko z racji działania w ośrodkach

${ }_{44}$ Pałamar (ukr.) - w ujęciu pejoratywnym oznaczał posługacza cerkiewnego lub dzwonnika.

45 Hej, tam na hori „Sicz” ide!..., s. 58-59.

${ }^{46}$ S. Hajduczok, Z nahody odnoho jubileju, „Sokilśki Wisty” 1930, nr 5-6, s. 4.

47 (en), Piate sjiczowe świato, „Narodne Słowo” 1910, nr 370, dodatek: „Wisty z Zaporoża”, nr 21 z 2 czerwca 1910, s. 12. p 


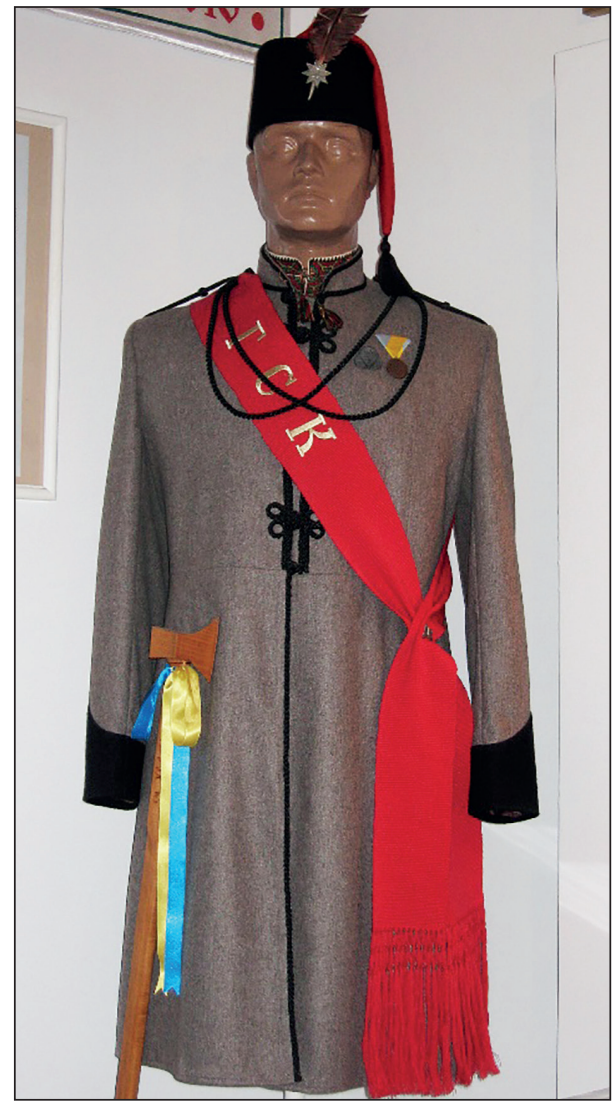

Zdj. 1. Oficjalny strój radykalnych towarzystw siczowych. Źródło: Galeria Ukraińskiego Wojskowego Munduru we Lwowie, p. Bogusława Lubiwa. Ze zbiorów własnych autora.

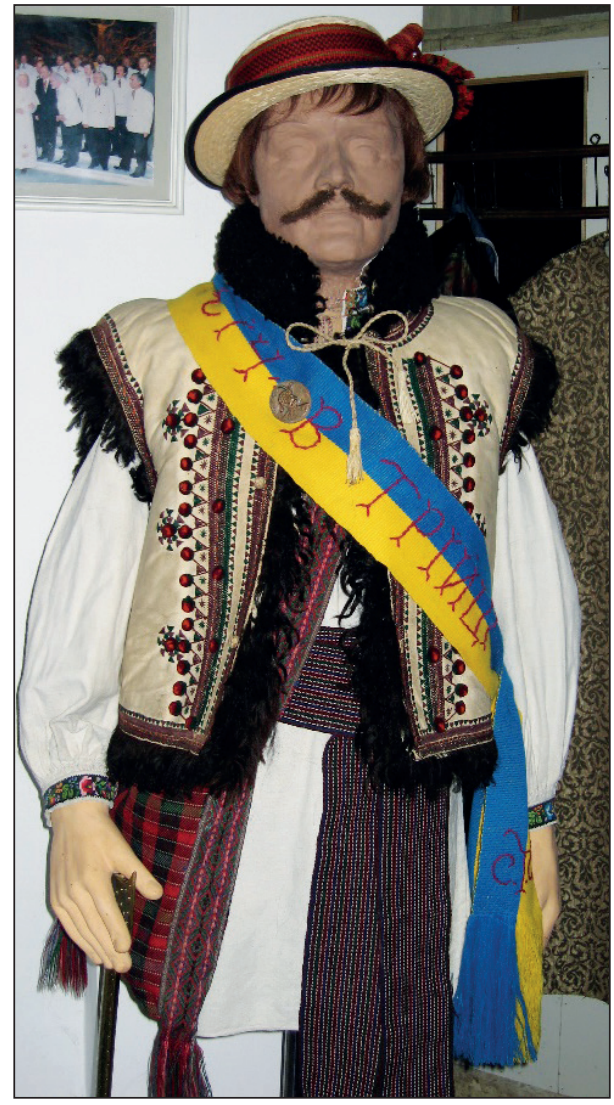

Zdj. 2. Tym, których nie stać było na zakup pełnego stroju siczowego, pozwalano na strój regionalny (huculski, pokucki) z organizacyjnymi dodatkami: huculskim drewnianym toporkiem, kapeluszem z piórem i odznaką. Całość przepasywano szarfą z napisem "Sicz” w ... [tu na zdj. z miejscowości Trójca]. Źródło: Galeria Ukraińskiego Wojskowego Munduru we Lwowie, p. Bogusława Lubiwa.

wiejskich „Siczom” doskwierał brak dostatecznej bazy sportowej, kadrowego zabezpieczenia i, co istotne, brak sportowych tradycji ${ }^{48}$. Te ostatnie były za to mocną stroną „Sokiła”. Prężnie natomiast rozwijała się, zarówno w jednym, jak i drugim towarzystwie, działalność przeciwpożarowa.

Istniejące różnice między związkami dostarczyły obaw przed kolejną wielką imprezą - Zlotem Sokolim w Pradze w dniach 28 czerwca - 1 lipca 1912 r., o to, czy powtórzy się na forum międzynarodowym sytuacja z Zagrzebia, z sierpnia roku 1911 i czy znowu ukraiński naród będzie reprezentowany przez dwie nieprzychyl-

48 O.M. Hudołyj, S.M. Fyl, G.W. Małka, Istorija fizycznoji kultury (Nawczalnyj posibnyk), Charkiw 2003, s. 111. 


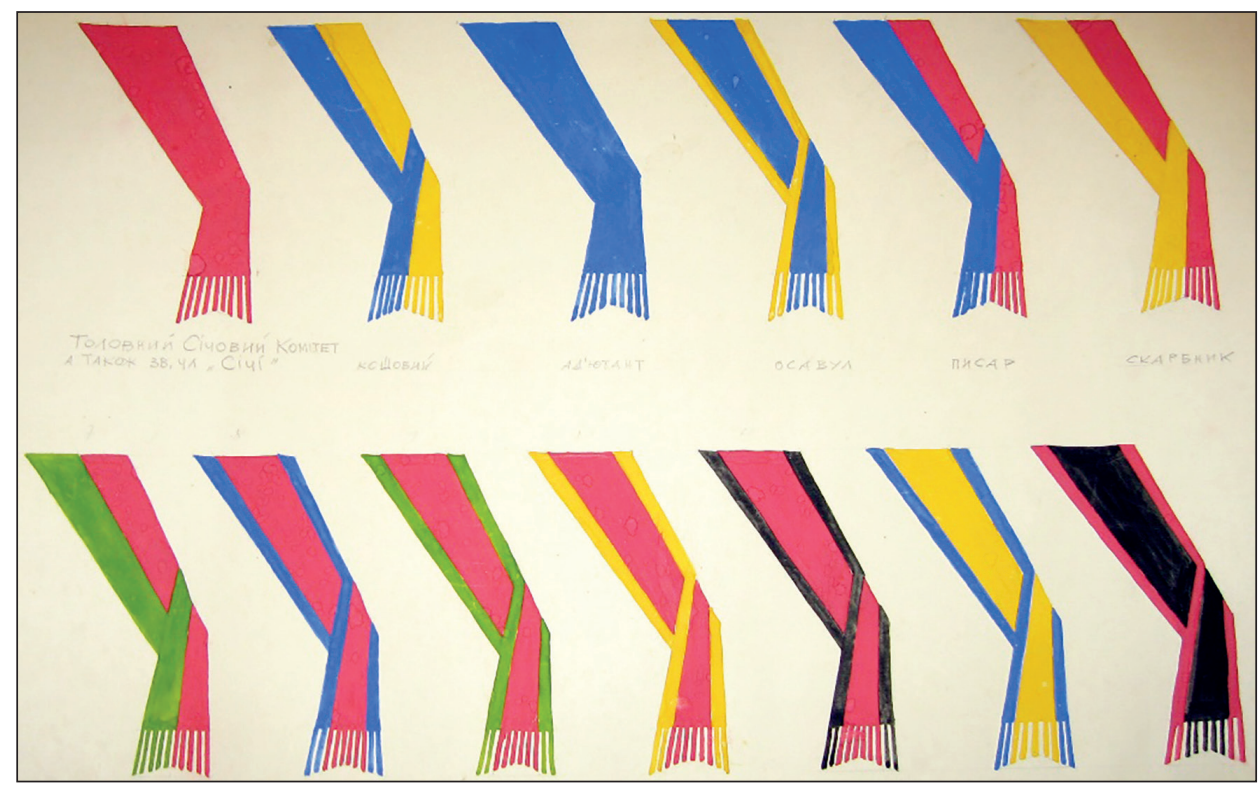

Zdj. 3. Kolory szarf używane w Związku Siczowym miały ścisłe hierarchiczne znaczenie. Górny rząd od lewej: malinowa - dla członków GKS i zwykłych członków „Siczy”; koszowy, adiutant, esauł, pisarz, skarbnik. Dolny rząd od lewej: oboźny, I czetar, II czetar, III czetar, IV czetar, chorąży, dobosz. Źródło: Galeria Ukraińskiego Wojskowego Munduru we Lwowie, p. Bogusława Lubiwa.

nie nastawione do siebie delegacje - radykalnej „Siczy” i „Sokiła-Batka”. Tak się też stało, ale zamiast „Siczy” wystąpiła tym razem niezapraszana przez nikogo delegacja ukraińskich moskalofilów. Na tablicy, którą w pochodzie przed nią niesiono, widniał napis „Rusini”49. Nie odegrała ona jednak żadnej roli.

Poza pojedynczym przypadkiem wspólnego świętowania „Sokiła” i „Siczy” w 1910 r. w Stanisławowie do krótkiego jednorazowego zjednoczenia obu central doszło dopiero w ramach przygotowań do Wielkiego Krajowego Zlotu Szewczenkowskiego w czerwcu $1914 \mathrm{r}^{50}$. Wspólny interes i waga chwili wymusiła na przywódcach dwóch największych central „Sokiła” i radykalnej „Siczy”, by pomimo wielu dotychczasowych uprzedzeń, schodząc się na jednej drodze do wolnej i niepodległej Ukrainy, podali sobie ręce. Jednak w przededniu tego wielkiego dla Ukraińców święta doszło do incydentu, który nawet u największych optymistów rozwiał wszelkie nadzieje na ostateczne połączenie obu wielkich organizacji. Chodziło o uroczystą mszę polową, która miała stanowić część składową Zlotu Szewczenkowskiego. Trylowśky, ku zdumieniu organizatorów, zdecydowanie oświadczył, że nie życzy sobie mszy na zlocie. W przeciwnym razie deklarował ostentacyjne opuszczenie zlotu lub wraz ze swoimi siczownikami groził zrobieniem na placu awantury ${ }^{51}$. W kręgach sokilskich

49 Grupa moskalofilów ukraińskich została zignorowana nawet przez delegację „Sokoła” rosyjskiego. „Wisty z Zaporoża”, nr 71, 31 lipca 1912, s. 1-2.

50 I. Andruchiw, Ukrajinśki mołodiżni towarystwa..., s. 18.

51 CDIAUL, F. 312, op. I, spr. 41, s. 226. 
zawrzało na, jak nazwano bez ogródek, podłość siczowego lidera. Było już jednak za późno na jakiekolwiek zmiany. Bez względu na to, co miało się wydarzyć, postanowiono nie zmieniać scenariusza. Zlot przebiegł bez zakłóceń, poza jednym wyjątkiem. Jeszcze w trakcie pokazów sprawności, po południu 28 czerwca, nadeszła z Sarajewa telegraficzna wiadomość o zamachu na arcyksięcia Franciszka Ferdynanda ${ }^{52}$. Wojna stała się faktem i to ona wymusiła sojusz, w czasie którego byli siczownicy i członkowie „Sokiła” podali sobie ręce w ramach nowej, czysto wojskowej organizacji - „Ukraińskich Siczowych Strzelców”53, a dotychczasowi szefowie organizacji gimnastycznych i strzeleckich połączyli wysiłki w pracach tzw. Ukrajińśkiej Bojewej Uprawy $^{54}$ - nadrzędnej komórki sprawującej władzę nad Siczowym Strzelectwem.

Chociaż dalszy opis działalności towarzystwa „Sicz” wykraczałby już poza ramy przyjętej cezury czasowej, z obowiązku wypada wspomnieć, że po wojnie ukraińsko-polskiej towarzystwa siczowe już nigdy nie powróciły do swojej świetności. W kontekście niedawnego konfliktu zbrojnego postrzegane były przez polskie władze jako niebezpieczne siedlisko ukraińskiego nacjonalizmu, szowinizmu, a tym samym jako zagrożenie dla bezpieczeństwa wewnętrznego państwa. Wobec powyższego, systematycznie zaczęto ograniczać działalność ruchu siczowego, a w maju 1926 r. definitywnie zabroniono działalności siczowych towarzystw. Najdłużej przetrwała filia w miejscowości Horbacze powiatu lwowskiego, istniejąca do jesieni roku 1930. Ale jeszcze w okresie działania „Siczy” zarząd organizacji podał do rejestracji projekty nowych statutów dla swoich towarzystw, o trzech różnych nazwach: „Sicz”, „Bractwo” i „Łuh”. Władze wyraziły zgodę na to ostatnie, stąd 25 marca 1925 r., po rejestracji statutu „Łuhu”, w miejscowości Podbereźce w powiecie lwowskim powstało pierwsze towarzystwo o tej samej nazwie. Z końcem 1926 r. istniało już około 600 nowych towarzystw „łuhowych”, a dotychczasowe „Sicze”, których działalności formalnie zabroniono, stopniowo zaczęły przenosić swoją aktywność pod parasol nowych struktur ${ }^{55}$.

52 Dodatkową atrakcją zlotu miały być zawody sportowe. Ze względu na wydarzenia w Sarajewie zostały odwołane.

53 T. Franko, Istorija i teorija..., s. 65.

54 Hołowną Ukrajińśką Radę tworzyli: Kost Łewyćki (przewodniczący), Mychajło Pawłyk i Mykoła Hankewycz (zastępcy) oraz Stepan Baran (sekretarz). Jej skład uzupełniali członkowie: Mykoła Bałyćki, Iwan Boberski, Iwan Kyweluk, Mykoła Łahodyńśki, Mychajło Łozyńśki, Teofil Mełeń, Wołodymyr Temnyćki, Kyrył Trylowśkyj, Wołodymyr Starosolski, Longin Cehielśki. Ukrajińśka Bojewa Uprawa składała się z dwóch sekcji: akcji i organizacji. Sekcję akcji tworzyli: Teodor Rożankowski (naczelnik), Dmytro Katamaj (zastępca naczelnika), Mychajło Wołoszyn i Mychajło Henyk (członkowie). Sekcja organizacji: Kyrył Trylowśkyj (szef), Stepan Szuchewycz (zastępca), Kost Birećki, Iwan Boberski, Sen Horuk, Wołodymyr Temnyćki.

55 R. Daszkewycz, Pidrucznyk dla ruchankowo-pożarnych towarystw „Siczej” ta „Łuhiw”, Lwiw 1926, s. 116. 


\section{Bibliografia}

\section{Źródła archiwalne:}

Centralnyj Derżawnyj Istorycznyj Archiw Ukrajiny m. Lwiw (CDIAUL), zespoły: Fond 312, opys I, sprawa 7.

F. 312, op. I, spr. 37, s. 1-2 (Księga protokołów 1894-1902).

F. 312, op. I, spr. 41, s. 226.

F. 312, op. I, spr. 169, ark. 4.

F. 146 (Hałyćke Namisnyctwo m. Lwiw 1772-1921), op. VIII, spr. 1040, s. 23.

F. 834, spr. 195 („Sicz - Towarzystwo Ukraińskich Studentów m. Wiedeń”, 1867-1913).

F. 847, op. I (Hołownyj Siczowyj Komitet Himnastycznoho i Pożeżnoho Towarystwa „Sicz” u Lwowi 1904-1914).

\section{Opracowania i artykuły:}

Atlas Ukrajiny i sumeżnych krajiw, red. W. Kubijowycz, Lwiw 1937, s. XLVIII, tab. nr $14,140$.

Andruchiw I., Ukrajinśki mołodiżni towarystwa Hałyczyny: 1861-1939 rr. (Korotkyj istorycznyj narys), Iwano-Frankiwśk 1995.

Daszkewycz R., Pidrucznyk dla ruchankowo-pożarnych towarystw „Siczej” ta „Łuhiw”, Lwiw 1926.

Dąbkowski T., Ukraiński ruch narodowy w Galicji Wschodniej 1912-1923, Warszawa 1985.

Franko T., Istorija i teoria ruchanky, Kołomyja-Lwiw 1923.

Hajduczok S., Piw stolittia sokilśkych wydań, Lwiw 1937.

Hajduczok S., Z nahody odnoho jubileju, „Sokilśki Wisty” 1930, nr 5-6.

Hej, tam na hori „Sicz” ide! Propamjatna knyha „Siczej”, zibraw i uporjadkuwaw Petro Trylowśkyj, Edmonton 1965.

Hrycak J., Historia Ukrainy 1772-1999. Narodziny nowoczesnego narodu, Lublin 2000. Hudołyj O.M., Fyl S.M., Małka G.W., Istorija fizycznoji kultury (Nawczalnyj posibnyk), Charkiw 2003.

Kowerko B.I., Sokilśkyj i siczowyj himnastycznyj ruch u Hałyczyni na poczatku XX stolittia [w:] Tradycji fizycznoji kultury w Ukrajini. Zbirnyk naukowych stattej, Kyjiw 1997.

Krypiakewycz I., Hnatewycz B., Stefaniw Z., Dumin O., Szramczenko S., Istorija Ukrajinśkoho Wijśka, t. II, Kyjiw 1995.

Kuzela Z., Czajkeskyj M., 1868-1908 „Sicz”. Almanach w pamjat' 40-ych rokowyn zasnuwannia Towarystwa „Sicz” u Widnji, Lwiw 1908.

Lubyżanin J., Ulitin O., Nahorniuk M., Do pytannia istoriji „Sokilśkich” ta „Siczowych” periodycznych wydań (do 1914 r.), „Pedahohika, Psychołohija ta MedykoBiołohiczni Problemy Fizycznoho Wychowannia i Sportu", nr 15, Specjalnyj wypusk za temoju: Tradyciji Ukrajinśkoji Fizycznoji Kultury i Formuwannia Systemy Fizycznoho Wychowannia w Ukrajini, czastyna I, Charkiw-Lwiw 2003. 
Partacz C., Od Badeniego do Potockiego. Stosunki polsko-ukraińskie w Galicji w latach 1888-1908, Toruń 1996.

Perszyj Ukrajinśkyj Proświtno-Ekonomicznyj Kongres, uładżennyj Towarystwom „Proświta” w soroklittia zasnuwannia u Lwowi. Protokoły i Referaty, red. dr I. Bryk i dr M. Kociuba, Lwiw 1910.

Tomczyk R., Z dziejów Ukraińskiego Ruchu Paramilitarnego w Galicji, Towarzystwo Gimnastyczne i Straży Ogniowej „Sicz”, „Przegląd Zachodniopomorski”, t. XXIV (LIII), z. 4, Rozprawy i Studia, Szczecin 2009.

Trofymiak B., Himnastyczno-sportywni orhanizaciji w nacionalno-wyzwolnomu rusi Hałyczyny, druha poł. XIX st. - persza poł. XX st., Ternopil 2001.

Ukrajinśki Czasopysy Lwowa 1848-1939, t. II: 1901-1919, red. M.M. Romaniuk, Lwiw 2002.

Waceba O., Narysy z istoriji zachidno-ukrajinśkoho sportywnoho ruchu, IwanoFrankiwsk 1997.

Wiśnicki J., Sprawa ukraińska jako element walki politycznej między konserwatystami a narodową demokracją w Galicji przed I wojna światowa, „Annales Universitatis Mariae Curie-Skłodowska Lublin - Polonia”, vol. I, sectio F, Lublin 1995.

Zaborniak S., Kultura fizyczna ludności ukraińskiej na ziemiach polskich (1868-1939), Rzeszów 2007.

\section{Wydawnictwa periodyczne:}

„Hromadśkyj Hołos” 1901.

„Siczowi Wisty” 1913.

„Sokilśki Wisty” 1908.

„Wisty z Zaporoża” 1910, 1912.

„Narodne Słowo” 1910, 1912.

Zaporożec. Kałendar dla naroda na rik zwyczajnyj 1911, Kołomyja 1910,

Zaporożec. Kałendar dla naroda na rik zwyczajnyj 1921, Wideń 1920. 


\section{Abstract}

\section{With 'Sokil' in the background. The founding and the development of the Ukrainian gymnastic and firefighting organization 'Sicz' (1900-1914)}

With the end of the 1970s, Galicia region was granted an autonomy. At the same time, the Austro-Hungarian monarchy granted the national minorities several concessions which allowed them to become more aware of their national identity. These concessions made the founding of organizations and associations possible. Ukrainians living in Galicia used this opportunity - thanks mainly to the initiative of 'Proswita' - to found their own educational, cultural and economic institutions, as well as sport associations, an example of which is 'Sokił'.

Frictions in the 'Sokił' association, only three years after its founding, halted its development and put the association in danger of dissolution. This temporary paralysis and loophole in the area was filled by an organization founded by a radical Kirył Trylowski. It was: Gymnastic and Firefighting Association 'Sicz', which in a relatively short time grew from its singular association into a finely functioning union gathering under its banner until the outbreak of war, in Galicia region, 800 branches.

'Sicz' took over the space left after the unstable and unreliable 'Sokił', at the same time becoming an alternative for those who did not trust in the future development of 'Sokil'. The one thing that attracted followers into the newly-founded 'Sicz' and distinguishing it from 'Sokił' which prided itself in Slavonic specifics, was the strictly national foundation of 'Sicz' and its focus on gathering the people from villages under one banner of gymnastic and firefighting organization. As the passage of time showed, the popularity of 'Sicz' was not due to it being a gymnastic and firefighting association, but due to the history, culture and national traditions that it firmly promoted.

Both the 'Sokił' and 'Sicz' movements which functioned alongside each other for a dozen of years, grew from the small, singular associations into finely functioning sprawling organizations that at the beginning od the $20^{\text {th }}$ century were the two most important gatherings of the Ukrainian gymnastic and firefighting movement. Both headquarters, although quite reluctant towards each other, intertwined, popularizing the national identity and national rebirth, and at the same time moulding the Ukrainian society into what they wanted. Although they rivaled, both organizations aspired to become, on the grounds of physical rebirth, the leading force of the nation.

When both organizations became quite numerous and their idea sufficiently promoted, the Sokit-Sicz cause lacked only the consolidation, because both headquarters had been foretold to have stellar futures if only they unite under one banner. However, due to differences too large to overcome: political, culturalhistorical, methodical, religious and even differing ambitions of the two associations - such a consolidation did not happen.

\section{Keywords:}

Ukrainian gymnastic and firefighting organization 'Sicz', Sicz, Sokil, Ukrainian Sport Association, Trylowski, Central Sicz Committee, Ukrainian Sicz Union 